\title{
Wieloaspektowość kształtowania księgozbioru biblioteki akademickiej na przykładzie Strategii zarzadzania zbiorami Docklands Library (University of East London)
}

\begin{abstract}
STRESzCzenie. W artykule scharakteryzowano aspekty kształtowania księgozbioru biblioteki akademickiej. Przedstawione zostały działania bezpośrednio i pośrednio dotyczące gromadzenia zbiorów w Docklands Library - jednej z trzech bibliotek wchodzących w skład Biblioteki Uniwersytetu Wschodniego Londynu. Najważniejsze czynniki mające wpływ na nabywanie księgozbioru w tej i innych bibliotekach akademickich to: potrzeby użytkownika, budżet, charakter naukowy uniwersytetu, przewidywane tendencje w rozwoju dyscyplin akademickich. Autorka wskazuje rolę biblioteki jako ośrodka, którego misja opiera się na utrzymaniu jak najwyższego poziomu merytorycznego księgozbioru i usług.
\end{abstract}

SŁowA KLUCzowe: biblioteka akademicka, użytkownik, zarządzanie biblioteka, konsorcjum biblioteczne, bibliotekarze dziedzinowi.

\section{Wstęp}

Kształtowanie księgozbioru biblioteki akademickiej jest zagadnieniem dotyczącym całej struktury bibliotecznej i głęboko angażującym bibliotekarzy różnych jednostek danej instytucji. To stwierdzenie, choć na pozór oczywiste, pozwala podkreślić filozofię współczesnego zarządzania w bibliotekach naukowych - świadome podejście do budowania zasobów i relacji z użytkownikiem. Związane z tymi elementami doświadczenia zdobyte podczas mojej wizyty w londyńskiej Docklands Library oraz lektura Strategii zarządzania zbiorami tejże biblioteki pozwoliły na wskazanie czynników wpływających na nabywanie księgozbioru. Celem 
artykułu jest przedstawienie narzędzi wspomagających gromadzenie wartościowego materiału w Docklands Library i przekazanie uniwersalnych spostrzeżeń na temat zarządzania zbiorami, mających lub mogących mieć zastosowanie $\mathrm{w}$ nowoczesnych bibliotekach akademickich, nie tylko w Wielkiej Brytanii.

\section{Charakter biblioteki}

Docklands Library jest druga, obok New Stratford Library, jednostką wchodzącą w skład Biblioteki Uniwersytetu Wschodniego Londynu, której księgozbiór ma odgrywać rolę zaplecza informacyjnego, głównie dla studentów i kadry naukowej tejże uczelni. Biblioteka w Docklands zainicjowała swoją działalność w 2000 roku, jako część pierwszego od pół wieku nowo wybudowanego kampusu uniwersyteckiego w Londynie. Status uniwersytetu nadano uczelni dopiero w 1992 roku, lecz już wcześniej miała ona bogatą tradycję w nauczaniu przedmiotów politechnicznych w roku 1898 utworzono Instytut Techniczny. Choć przekształcając politechnikę w Uniwersytet Wschodniego Londynu, pozostawiono w programie kształcenia kierunki techniczne - architekturę, budownictwo lądowe, informatykę, elektronikę - to obecnie wiele jest też takich, które nie są związane z tymi gałęziami wiedzy, jak choćby: psychologia, prawo, pedagogika, biznes i ekonomia, kierunki adresowane do studentów o zainteresowaniach związanych z medycyną i szeroko pojętą aktywnością zdrowotna, także sztuka, filmem, mediami, modą czy dziennikarstwem ${ }^{1}$. Szeroki zakres dyscyplin na uniwersytecie pociąga za sobą konieczność gromadzenia w kampusach różnorodnego księgozbioru o wysokiej jakości merytorycznej. Biblioteka w Docklands dba o nabywanie literatury obejmującej między innymi biznes, ekonomię i finanse, inżynierię, sztukę i architekturę, historię, antropologię, dziennikarstwo ${ }^{2}$. Ze względu na fakt, iż jest ona częścią biblioteki akademickiej, jej głównym celem jest spełnianie oczekiwań studentów i kadry naukowej dotyczących wartości naukowej zbiorów i wysokiej jakości ich udostępniania. Działanie takie jest charakterystyczne dla bibliotek akademickich w nowoczesnym sposobie zarządzania jakością.

1 University of East London [online], [dostęp: 17.07.2013], dostępny w internecie: http://en.wikipedia.org/wiki/University_of_East_London.

2 Strona internetowa Docklands Library: Library and Learning Services [online], [dostęp: 17.07.2013], dostępny w internecie: http://www.uel.ac.uk/lls/about/ docklands/. 
Związane jest ono [zarządzanie jakością - M.B.] z odmiennym kształtowaniem się charakteru bibliotek, które od początku XX w. zmieniły swoje podejście do użytkowników, nadając im pierwszoplanowy charakter. Stały się instytucjami bardziej otwartymi, skierowanymi w stronę otoczenia i dążącymi do zaspokajania jego potrzeb i oczekiwań, zabiegającymi o czytelników i oferującymi im szeroką gamę usług³.

\section{Księgozbiór a misja}

Podejmując się roli przewodnika, biblioteka jest zobowiązana dbać o wysoką jakość księgozbioru nabytego w sposób najbardziej korzystny finansowo. Biblioteki w Wielkiej Brytanii starają się osiągnąć ten cel przez przynależność do konsorcjów. W zakresie pozyskiwania książek i czasopism, w wersji zarówno drukowanej, jak i elektronicznej, Docklands Library jest członkiem London Universities Purchasing Consortium ${ }^{4}$, którego zadaniem jest przede wszystkim zapewnianie atrakcyjnych cen nabywanych źródeł informacji. Bibliotekarze w Docklands szacują iż w roku 2013 zniżka w przypadku wersji drukowanej czasopism i książek wynosi około 11-12\%, natomiast w przypadku książek elektronicznych - 5\%. Zakres umów obowiązujących dostawców w ramach konsorcjów obejmuje również inne usługi związane z fizycznym przygotowaniem zasobu do udostępniania. Jest to nadawanie znaków własnościowych, zabezpieczanie okładek przed zużyciem. W ramach usług proponowanych przez wydawcę są także takie, które znacząco pomagają opracować księgozbiór, jak choćby katalogowanie i klasyfikowanie nowych jednostek zgodnie z najwyższymi standardami ${ }^{5}$.

Te i inne aspekty zarządzania księgozbiorem Docklands Library określa Strategia zarządzania zbiorami (Collections Management Strategy), której szczegółową wersją jest umieszczona na stronie internetowej University of East London Polityka zarzadzania zbiorami (Collection Management Policy) ${ }^{6}$. Wskazują one na cel budowania kolekcji oraz jakość, ilość i charakter zbiorów, co w założeniu ma się przyczynić do zadowolenia

3 M. Wojciechowska, Zarzadzanie zmianami w bibliotece, Warszawa 2006, s. 139.

4 Strona internetowa London Universities Consortium [online], [dostęp: 17.07. 2013], dostępny w internecie: http://www.lupc.ac.uk/agreements/commodities.aspx? AgreementID=258.

5 S. Francis, Academic libraries and the financial crisis: experiences from Britain, „Zarządzanie Biblioteką" 2009, nr 1 (1), s. 124.

6 Library Policies - Collection Management Policy [online], [dostęp: 17.07.2013], dostępny w internecie: http://www.uel.ac.uk/lls/services/basicpolicy9/. 
użytkowników i pozytywnie wpływać na całościowy wizerunek instytucji ${ }^{7}$. Podobnie dzieje się w polskich bibliotekach akademickich, gdzie dąży się do sformułowania zasad nabywania księgozbioru. Przykładem takiego dokumentu jest Polityka zarzadzania zasobami w systemie biblioteczno-informacyjnym UAM, która podejmuje szczegółowe kwestie nabywania księgozbioru i bierze pod uwagę współpracę wewnątrz środowiska akademickiego ${ }^{8}$.

Kluczem do zrozumienia roli biblioteki naukowej w różnych środowiskach akademickich jest określenie jej charakteru i wytyczenie podstawowych zadań, które stanowiłyby realizację strategicznych celów organizacji. Pojmowanie celów formułuje się następująco:

Biblioteka powinna rozwijać posłannictwo, cele i zadania w zgodzie z założeniami macierzystej uczelni i strategią informacji. Zadania te powinny być określone w drodze konsultacji, w których uczestnikami powinni być bibliotekarze, klienci biblioteki i władze uczelni9.

Założenia polityki gromadzenia, m.in. w polskich bibliotekach akademickich, przeanalizował na podstawie przeprowadzonych ankiet Zdzisław Gębołyś w artykule Zasady gromadzenia zbiorów w bibliotekach uniwersyteckich: doświadczenia polskie $i$ zagraniczne, w którym wskazuje na jedno z pomocniczych kryteriów w procesie formowania zbiorów, a mianowicie - celowość ${ }^{10}$. Kryterium to jest kluczowe dla wysokiej jakości zbiorów i usług bibliotecznych - pozyskiwanie cennego merytorycznie materiału bibliotecznego $\mathrm{w}$ odpowiedzi na artykułowane potrzeby środowiska zewnętrznego. Powyższe wskazania podkreślają konieczność współpracy zarówno wewnątrz biblioteki, jak i ze środowiskiem akademickim pojmowanym jako całość (studenci, nauczyciele akademiccy). Zajmując się różnorodnymi dziedzinami wiedzy, członkowie

7 G. Sandhu, L. Homer, Collections Management Strategy [online], [dostęp: 29.04.2013], dostępny w internecie: http://www.uel.ac.uk/wwwmedia/services/library/lls/resources/documents/CollectionsManagementStrategy_final.doc.

8 Polityka zarzadzania zasobami w systemie biblioteczno-informacyjnym UAM [online], [dostęp: 18.07.2013], dostępny w internecie: http://lib.amu.edu.pl/index. php?option=com_content\&task=view \&id=1278\&Itemid=193.

9 K. Ennis, Wytyczne dla bibliotek akademickich, w: Zarzadzanie biblioteka. Najnowsze kierunki w bibliotekarstwie brytyjskim, red. I. Kemp, T. Wildhardt, Warszawa 1998, s. 50.

10 Por. Z. Gębołyś, Zasady gromadzenia zbiorów w bibliotekach uniwersyteckich: doświadczenia polskie i zagraniczne, w: Strategie gromadzenia zbiorów w bibliotekach polskich, red. U. Ganakowska [online], [dostęp: 17.07.2013], dostępny w internecie: http://zbc. ksiaznica.szczecin.pl/Content/29173/Seria_BZP_T_IX.pdf, s. 16. 
środowiska akademickiego spodziewają się bowiem, że zapleczem każdej z nich będzie dobrze zorganizowany, wysokiej jakości księgozbiór. Owe oczekiwania nie mogą być jednostronne. W Strategii zarządzania zbiorami podkreślono jednoczesne zaangażowanie $\mathrm{w}$ tworzenie księgozbioru środowiska akademickiego i bibliotekarzy oraz konieczność przełożenia ogólnych założeń na konkretne działania.

\section{Strategia funkcjonowania Docklands Library}

$\mathrm{W}$ analizowanym systemie do podstawowych aktywności biblioteki akademickiej należą: komunikacja wspomnianych środowisk za pośrednictwem bibliotekarzy dziedzinowych; coroczne spotkania dotyczące charakteru księgozbioru z komitetem studenckim; kontakty za pośrednictwem bibliotecznej strony internetowej, ułatwiającej szybką reakcję na propozycje dotyczące księgozbioru czy usług i umożliwiającej otrzymywanie informacji zwrotnych na ich temat. Poszczególne warianty działań nie są od siebie oddzielone, lecz wzajemnie się uzupełniają. Podczas wizyty w Docklands Library można było zauważyć, iż bibliotekarze dziedzinowi aktywnie udzielają się w ramach usługi Ask a Librarian, a jednocześnie mają okazję do bezpośredniej wymiany doświadczeń ze specjalnie delegowanymi pracownikami wydziałów. Wspólnie decydują o nabywaniu konkretnej literatury.

Innym sposobem kształtowania księgozbioru są listy lektur, których uzgadnianie jest zasadnicze dla najbardziej efektywnego i zadowalającego użytkowników gromadzenia źródeł informacji, a także wykorzystania środków finansowych, tym bardziej że bibliotekarze dziedzinowi mają informować wydziały co dwa miesiące o ich wykorzystaniu. W tym kontekście należy zauważyć podobieństwo do działań w polskich bibliotekach akademickich. Biblioteka Uniwersytecka w Poznaniu uruchomiła $\mathrm{w}$ ramach kontaktów z wydziałami portale dziedzinowe mające służyć pomocą $\mathrm{w}$ wyszukiwaniu specjalistycznych informacji ${ }^{11}$. Priorytetem dla Docklands Library jest również gromadzenie literatury naukowej w dogodnej dla użytkownika formie i na odpowiadającym mu nośniku. Duży nacisk położony jest na nabywanie wydawnictw elektronicznych, szczególnie czasopism oraz baz danych. W bibliotece, zgodnie $\mathrm{z}$ informacjami przekazanymi przez pracujących tam bibliotekarzy, znajdują

${ }^{11}$ Strona internetowa Biblioteki Uniwersyteckiej w Poznaniu: Portale dziedzinowe [online], [dostęp: 18.07.2013], dostępny w internecie: http://lib.amu.edu.pl/index. php?option=com_content\&task=view \&id=1244\&Itemid=279. 
się: 11394 książki elektroniczne i 57941 czasopism elektronicznych oraz 45 baz danych. Oprócz nich do celów edukacyjnych dostarcza się nagrań i materiałów wizualnych. Czasopisma elektroniczne kupowane są na zamówienie wydziałów, a dodatkowo o nabyciu decydują: ich wysoki poziom, dobór do programu nauczania konkretnych uniwersyteckich kursów oraz cena. Wymienione zasady są zgodne ze strategią zarządzania Just in Time, która determinuje współczesne spojrzenie nie tylko na kolekcjonowanie materiałów, ale także na sposób ich udostępniania klientowi. Priorytetowa jest oczywiście dbałość o merytoryczną wartość gromadzonych zbiorów, ale nie mniej ważny jest czas, w jakim informacja o nich dotrze do odbiorcy.

Wśród pierwszoplanowych elementów strategii Just in Time stosowanych w bibliotece są przede wszystkim: ciągłe dążenia do podnoszenia jakości usług, szybka reakcja na zmiany w otoczeniu biblioteki; szybkie dostosowywanie się do potrzeb użytkowników; nastawienie na e-źródła; skrócenie czasu oczekiwania na usługę, zaangażowanie bibliotekarzy i podnoszenie ich kompetencji; eliminacja marnotrawstwa i strat ${ }^{12}$.

Istotnym elementem strategii nabywania zbiorów jest oszacowanie ewentualnych kosztów dostarczenia źródeł informacji do czytelnika, dzięki czemu możliwe jest racjonalne planowanie budżetu biblioteki. Z informacji przekazanych przez bibliotekarzy w Docklands wynika, że koszt zakupu książki w wersji drukowanej wraz z umieszczeniem jej na półce to około 60 GBP. Powyższe rozważania, poparte Analiza SWOT zawartą w Strategii zarządzania zbiorami, pozwalają przewidywać przyszłe kroki w zakresie finansowania, rodzajów i ilości nabywanego księgozbioru. Ważne jest zachowanie proporcji pomiędzy liczbą studentów poszczególnych kierunków a liczbą tzw. core texts - jedna kopia na ośmiu uczestników biorących udział w kursie danego przedmiotu ${ }^{13}$. Szacowanie kosztów jest szczególnie istotne dla biblioteki, której pracownicy są świadomi, że nie wyróżniają ich ważne czy cenne zbiory i nie mogą konkurować z takimi bibliotekami jak chociażby The British Library. W dobie zapewniania zdalnego dostępu do źródeł istnieje też ryzyko, że przestrzeń biblioteki nie będzie odwiedzana przez zainteresowanych. Próbą rozwiązania tych problemów jest promowanie kolekcji, którymi biblioteka się szczyci i które uważa za podstawę dalszego rozwoju księgozbioru. Nie mogąc mówić o całości swoich zbiorów jako unikatowych, Docklands Library

\footnotetext{
${ }^{12}$ Por. M. Wojciechowska, op.cit., s. 215-224.

${ }^{13}$ G. Sandhu, L. Homer, op.cit.
} 
wyodrębnia te, które nadają bibliotece wartość ponadczasową. Najważniejsze z nich to Refugee Archive oraz British Olympic Association Archive. Podkreślają one związek biblioteki z tradycją i pozwalają postrzegać ją jako kształtującą swoją kulturę organizacyjna, nawet jeśli nie jest ona zbudowana na latach doświadczeń. Powyższe kolekcje określają tożsamość kulturową biblioteki, podobnie jak w Polsce elementem komunikującym związek z tradycją są zbiory specjalne.

Założenia kulturowe uznawane w bibliotekach powiązane są w sposób ścisły z historią kraju (utrata cennych zbiorów), historią uczelni oraz samej biblioteki (kształtowanie się zbiorów, dyrektorzy, ważne wydarzenia) $)^{14}$.

Archiwum Brytyjskiego Stowarzyszenia Olimpijskiego nawiązuje do tradycji organizowania przez Wielką Brytanię igrzysk, przypomina wydarzenia z pierwszych tego typu zawodów w tym kraju w 1948 roku. Kolekcja dotycząca imigrantów zwraca uwagę na bogactwo etniczne państwa i uniwersytetu, który ze względu na swoje położenie geograficzne - bliskość Europy - staje się azylem dla społeczności akademickich innych niż brytyjska. Uniwersytet Wschodniego Londynu, a zatem także Docklands Library, stara się podkreślać swoje otwarcie na studentów międzynarodowych oraz tych z mniej zamożnych środowisk, by wyrównywać szanse dostępu do nauczania, czyli takiego samego prawa do korzystania z księgozbioru bibliotecznego. W tym celu powstają specjalne ulotki, a oprócz nich działają Łzw. study skills advisors, którzy wspierają bibliotekarzy dziedzinowych w komunikacji ze studentami pierwszych i ostatnich lat, ucza, jak gromadzić bibliografię, tworzyć przypisy, a następnie pomagają przy pisaniu prac magisterskich. W ten sposób biblioteka staje się „miejscem spotkań" środowiska zewnętrznego z bibliotekarzami, którzy nie są już postrzegani jako personel „podający” książki, lecz wyspecjalizowana kadra, mogąca udzielać informacji bezpośrednio czy online na temat księgozbioru i sposobów posługiwania się nim.

\section{Komunikacja z użytkownikiem a wizerunek biblioteki}

Powyższe rozważania nasuwają wniosek o związku pomiędzy rodzajem nabywanego księgozbioru a komunikacją wewnątrz i na zewnątrz biblioteki. Nawet najlepszy sposób organizacji zbiorów nie spełni swojej

${ }^{14}$ M. Całka, Kultura organizacyjna biblioteki akademickiej - nowe wyzwania i szanse, „Zarządzanie Biblioteką" 2011, nr 1 (3), s. 39. 
funkcji, jeśli procesowi ich nabywania nie będzie towarzyszyło uwzględnianie potrzeb użytkowników. Kształtując księgozbiór dla konkretnych odbiorców, tworząc miejsce do pracy, biblioteka odpowiada na potrzeby użytkowników, a jednocześnie komunikuje swoją wartość i potrzebę istnienia w środowisku uniwersyteckim.

Niektóre dyscypliny wyżej cenią kolekcje drukowane, podczas gdy inne mogą bardziej polegać na źródłach elektronicznych. [...] Bibliotekarze muszą być aktywnymi uczestnikami rozmów odbywających się w kampusach uniwersyteckich, aby zwiększyć świadomość kadry uniwersyteckiej i rozumienie różnych sposobów, dzięki którym biblioteka przyczynia się do wypełniania misji instytucji ${ }^{15}$.

Po raz kolejny okazuje się, że zarządzanie zbiorami to dbałość o celowość doboru księgozbioru, wiążące się z szeregiem działań testujących nie tylko merytoryczną wiedzę bibliotekarzy, ale także umiejętności interpersonalne, które są punktem wyjścia do zbudowania pozytywnego wizerunku biblioteki. Docklands Library jest przykładem instytucji dbającej o zaplecze naukowe - nieustannie konfrontuje je $\mathrm{z}$ oczekiwaniami tych, dla których jest ono tworzone. Gromadzenie książek czy czasopism nigdy nie istnieje samo dla siebie, ale jest wynikiem dyskusji środowiska zewnętrznego i biblioteki. W Polsce biblioteki uruchomiły oprócz serwisu Ask a Librarian także usługę Zaproponuj kupno ksiażki oraz Biblioteka poszukuje, starają się również prezentować zakupione nowości ${ }^{16}$. Wyartykułowane potrzeby konfrontuje się z możliwościami ich realizacji, biorąc pod uwagę czynniki ekonomiczne, przestrzenne, przewidywania co do przyszłych zadań uczelni. Rezultatem powinna być analiza dotycząca zawartości księgozbioru i jego wykorzystania. Obok tradycyjnych metod, takich jak statystyki wykorzystania kolekcji, biblioteka w Docklands gromadzi

${ }^{15}$ K. Brown, K.J. Malenfant, Connect, Collaborate, and Communicate. A Report from the Value of Academic Libraries Summits [online], [dostęp: 02.05.2013], dostępny w internecie: http://www.ala.org/acrl/sites/ala.org.acrl/files/content/issues/value/val_summit.pdf, s. 8, tłum. - M.B.

${ }^{16}$ Por. strona internetowa Biblioteki Uniwersyteckiej w Poznaniu: Zaproponuj kupno książki do zbiorów Biblioteki Uniwersyteckiej w Poznaniu [online], [dostęp: 18.07.2013], dostępny w internecie: http://lib.amu.edu.pl/index.php?option=com_content\&task=view\&id=1027\&Itemid=267; strona internetowa Biblioteki Uniwersytetu Gdańskiego: Biblioteka poszukuje [online], [dostęp: 18.07.2013], dostępny w internecie: http:// www.bg.ug.edu.pl/biblioteka-poszukuje; strona internetowa Biblioteki Jagiellońskiej: Lista nabytków [online], [dostęp: 18.07.2013], dostępny w internecie: http://www.bj.uj. edu.pl/zb/lbazyz1_pl.php. 
dane na podstawie informacji zwrotnych od użytkownika. W tym celu wykorzystuje się każdą okazję (spotkania, korespondencja e-mail itd.) do zgromadzenia danych o tym, co udało się bibliotece osiągnąć w zakresie realizacji potrzeb użytkowników, a co wymaga korekty i w jakim stopniu jest ona możliwa. Jedną z form kontaktu z odbiorcą jest strona You said... we $\operatorname{did}^{17}$, która zawiera odpowiedzi na pytania czy problemy zgłaszane przez użytkowników wysyłających e-maile do konkretnego pracownika lub wypełniających tzw. Feedback Form. Kontakt ten jest okazją do rozwiania wątpliwości dotyczących usług bibliotecznych, po to by nie powielano mylnych informacji, które uderzają w środowisko bibliotekarskie i podważają jego status. W tym kontekście działania wyjaśniające i promujące nowe usługi oraz księgozbiór zmniejszają ryzyko stereotypowego postrzegania biblioteki i bibliotekarzy. Oprócz internetowego sposobu porozumiewania się środowisk bibliotekarze w Docklands starają się podtrzymywać bezpośrednie kontakty ze środowiskiem akademickim w ramach: Students' Experience Committee, Learning and Teaching Committee oraz Academic Integrity. Ostatecznym sprawdzianem jest ankieta wypełniana przez studentów ostatniego roku studiów -National Students' Survey, dotycząca działalności uniwersytetu i biblioteki, której wyniki są przeliczane na punkty i trafiają do rankingu uniwersytetów w Wielkiej Brytanii. Wszystkie te działania podejmowane są w celu kreowania pozytywnego wizerunku siebie i swojego miejsca pracy. Kluczem do porozumienia jest bowiem szerzenie wiedzy na temat bibliotek $^{18}$.

\section{Podsumowanie}

Analiza kształtowania księgozbioru Docklands Library ujawniła wiele działań towarzyszących temu procesowi, choć bezpośrednio z nim niezwiązanych. Wnioski są aktualne na gruncie zarządzania zbiorami także innych bibliotek akademickich:

- nabywanie księgozbioru powinna poprzedzać refleksja, dla kogo i w jakim celu jest on tworzony,

- świadome kształtowanie zbiorów to połączenie merytorycznej jakości nabywanego materiału z potrzebami użytkowników.

17 Strona internetowa UEL: Library and Learning Services [online], [dostęp: 17.07.2013], dostępny w internecie: http://www.uel.ac.uk/lls/about/you_said/\#current.

${ }^{18} \mathrm{~J}$. Sobocha-Stanuch, P. Picheta, Stereotypy bibliotekarzy [online], [dostęp: 03.05.2013], dostępny w internecie: http://www.profuturo.agh.edu.pl/pliki/Pliki_III_ KKMU/Zbiory_referatow/607-614_NH_Sobocha-Stanuch_Picheta.pdf, s. 611. 
Podsumowując, należy podkreślić konieczność współpracy bibliotekarzy i środowiska akademickiego w zakresie podejmowania decyzji o nabywaniu księgozbioru, która obok aspektów finansowych, informacyjnych czy historycznych jest kluczowa dla wartości i wizerunku biblioteki.

\author{
MAŁGORZATA BRÓDKA
}

\title{
A multifaceted approach to shaping academic library collections with the example of the Collection Management Strategy, Docklands Library (University of East London)
}

\begin{abstract}
Aвstract. The present article describes and discusses the aspects of structuring a library collection in an academic library. Direct and indirect actions aimed at improving the acquisitions policy at Docklands Library, one of the three libraries comprising the East London Library, are presented. The most important factors influencing acquisition at this, as well as other academic libraries, include: user's needs, budget, research mission of the university, and envisaged tendencies in the development of academic disciplines. In conclusion, the author identifies the role of the library as a center whose mission is to maintain the highest possible substantive level of its book collection and provided services.
\end{abstract}

KEY wORDs: academic library, library user, library management, library consortium, subject specialists. 